\title{
Gamma Radiation Shielding and Thermal Properties of the polystyrene / Tungsten (VI) Oxide Composites
}

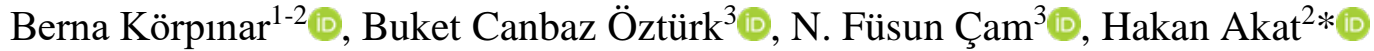 \\ ${ }^{1}$ Manisa Celal Bayar University, Faculty of Arts and Science, Department of Chemistry, 45140 Yunusemre, \\ Manisa, Turkey \\ 2 Ege University, Faculty of Science, Department of Chemistry, 35100 Bornova, Izmir, Turkey \\ ${ }^{3}$ Ege University, Faculty of Science, Department of Physics, 35100 Bornova, Izmir, Turkey
}

Geliş / Received: 07/02/2021, Kabul / Accepted: 15/04/2021

\begin{abstract}
In the current study, it was shown that polystyrene (PS) composites holding tungsten (VI) oxide were formed in groups (10\% to $50 \%$ ) by radical polymerization. For this goal, the styrene reacted with BPO for 2.5 hours at $70{ }^{\circ} \mathrm{C}$ in tetrahydrofuran (THF) to give the consistent polymer. Synthesized PS were defined by FTIR, GPC $(\mathrm{Mn}=7900 \mathrm{~g} / \mathrm{mol} \mathrm{PDI}=1.66)$, SEM and 1H NMR spectroscopy. PS-tungsten (VI) oxide composites formed between $80-85^{\circ} \mathrm{C}$. The gamma-ray of composites was calculated using the $\mathrm{NaI}(\mathrm{Tl})$ scintillation detector. Linear attenuation coefficients were also estimated hypothetically by the XCOM platform, taking into account the fundamental analysis of composites and comparing them with empirical outcomes. Among the composites studied, the best protective material was PS -50\% W03 with lower absorption thicknesses and a higher linear slimming coefficient. Thermal degradation of unirradiated and irradiated polymer composites has also been examined.
\end{abstract}

Keywords: Polystyrene, transmission parameters. polymer-composites, tungsten(VI) oxide, gamma-ray mass attenuation.

\section{Polistiren / Tungsten (VI) Oksit Kompozitlerin Gama Radyasyon Durdurma ve Termal Özellikleri}

\section{Öz}

Bu çalışmada, radikal polimerizasyon ile tungsten (VI) oksit polistiren (PS) kompozitlerin gruplar halinde (\% 10-\% 50) oluştuğu gösterilmiştir. Bu amaç için stiren, istenilen polimeri vermek üzere tetrahidrofuran (THF) içinde $70^{\circ}$ C'de BPO ile 2.5 saat reaksiyona girdi. Sentezlenen PS, FTIR, GPC $(\mathrm{Mn}=7900 \mathrm{~g} / \mathrm{mol}$ PDI = 1.66), SEM ve ${ }^{1} \mathrm{H}$ NMR spektroskopisi ile tanımlandı. 80-85 ${ }^{\circ} \mathrm{C}$ arasında oluşan PS-tungsten (VI) oksit kompozitlerin gama 1şını, NaI (Tl) sintilasyon detektörü kullanılarak hesapland1. Lineer soğurma katsayıları, bileşiklerin temel analizi dikkate alınarak ve deneysel sonuçlarla karşılaştırılarak XCOM platformu tarafından varsayımsal olarak da hesapland. İncelenen kompozitler arasında en iyi koruyucu malzeme, daha düşük absorpsiyon kalınlıkları ve daha yüksek lineer soğurma katsayısı ile PS-\%50 W03'tir. Işınlanmamış ve ışınlanmış polimer kompozitlerin termal bozunması da incelenmiştir.

Anahtar Kelimeler: Polistiren, geçirgenlik parametreleri, polimer kompozitler, tungsten (VI) oksit, gama 1şını kütle soğurması. 


\section{Introduction}

Nuclear energy has many applications in different fields such as medicine, industry, agriculture, etc. Although these great benefits, the radiation has a risk to humans health so it is important to protect against it by designing a shield between the radiation source and the surrounding environment. Generally, the radiations that must be considered are neutron and gamma where each of them has a different way of interaction with the matter for that it's important to study the attenuation of these rays in the materials to choose the most effective shield depending on radiation type and its energy (Darwood, 2017; Knoll, 2000; Tsoulfanidis, 1995). Different materials can be designed for radiation protection. For instance, concrete, tungsten, steel, and lead are the most successfully used for gamma-ray shielding. Lead-shields are frequently used in fields where space is limited (Harrison, 2008; Erdem, 2010). Nevertheless the largest deficit of lead is that it is poisonous (Lamarsh, 2001). Steel or Iron is also a public gamma-ray shielding material but it is a very exclusive material. Concrete is often used in the building of great capacity shields of little capacity. Tungsten is an appealing material for small shields or collimators. Styrene butadiene - styrene copolymer and tungsten could be obtained as a new material additional to lead. They studied with the Monte Carlo method (Gobartkina, 2007). Yue K et al reported that a new polymer composite material can be used for radiation shielding without lead (Yue, 2008). Ivanova et al reported that polymermetal composites could be used for radiation shielding in radiotherapy. Bobadilla-Sánchez et al worked with the concrete-polyester mixture. They have studied the potential of shielding materials (Bobadilla-Sánchez,2009; Martínez-Barrera, 2013). Lead, bronze, copper, and ferrous metals besides polymer composite metals have been compared. (Durkee, 2005). As a material, Polystyrene is a solid, transparent plastic raw material made by polymerization of styrene monomer. In the world, the most used plastic for general purpose is among the top five in the raw material ranking. It is preferred because of its transparency, good processability, fluidity, food suitability, and many other properties. Polystyrene (PS) is a type of thermoplastic which has a wide range of uses. Polystyrene (PS) is classified as Antishock (HIPS), Crystal, and Foam according to the processing method. Polystyrene (PS) is used in many industries to replace paper, wood, and metals. It is usually used in film fabric coatings, insulation boards, lighting materials, refrigerator-washing machine components, battery boxes, radio and television cases, toys, and household goods. As a result, it may be important to form a composite of polystyrene containing tungsten oxide and examine its properties. In this study, tungsten (VI) oxide with different concentrations (10, 20, 30, 40, 50) \% has been added to polystyrene to study shield designs that can be used to reduce radiation danger.

\section{Materials and Methods}

\subsection{Materials}

Benzoyl peroxide (BPO, 98\% Merck). Diethyl ether (98\%, Merck). Methanol (99\%, Riedel) Tetrahyrafuran (99\% Sigma Aldrich). Ethanol (99\% Sigma-Aldrich). Sodium tungstate dihydrate (99\%, Merck). Dichloromethane (99\%, Merck Company). Dimethylformamide (DMF 99\%, Merck Company,). Styrene (99\%, Merck Company). Hydrochloric acid (ACS reagent, 37\% Merck Company). 


\subsection{Instrumentation}

The molecular weight of polystyrene is determined by gel permeability chromatography. THF as an eluent is used at the run rate of $1 \mathrm{~mL} / \mathrm{min}$ (RI detector). FTIR spectra were noted in a PerkinElmer FTIR Spectrometer. TGA measurements of composites were made on Perkin Elmer Diamond TA/TGA between 30 and $1000{ }^{\circ} \mathrm{C}$ with the heating speed at $10{ }^{\circ} \mathrm{C} / \mathrm{min}$ under the nitrogen atmosphere. Sample weights were taken between 9-10 mg. SEM images obtained $6.0 \mathrm{~mm}$ using an area Thermo Scientific Apreo S emission-scanning electron microscope. Xray diffraction analyses were obtained by Panalytical Empyrean diffractometer. 1H-NMR measurements were noted in deuterium chloroform using varian AS-400 device.

\subsection{Synthesis of polystyrene}

$25 \mathrm{ml}$ ( $0.22 \mathrm{~mol})$ Styrene were added in $25 \mathrm{~mL}$ of THF (0.012 mol).After that, BPO (1\%) was added to this solution. This solution was agitated for $2 \mathrm{~h}$ at $70^{\circ} \mathrm{C}$. Polystyrene was precipitated in methanol. ${ }^{1} \mathrm{H}$ NMR (DMSO-d8, $400 \mathrm{MHz}$ ) 7,5-6,5ppm (b 5H, CH) 1.5-2ppm (b, 1H, $\mathrm{CH}_{2}$ ), 1-1.5ppm (b, 2H,CH$)$, (FTIR cm $\left.{ }^{-1}\right) 3000\left(-\mathrm{CH}_{2}\right)$,2852 $\left(-\mathrm{CH}_{2}\right), 1780-200$ overtones, $1630(\mathrm{C}=\mathrm{C})$ benzene ring,800, 760, $550 \mathrm{~cm}^{-1} \mathrm{Mn}=7900 \mathrm{PDI}=1.66$.

\subsection{Synthesis of $\mathrm{WO}_{3} .2 \mathrm{H}_{2} \mathrm{O}$}

The $\mathrm{WO}_{3} .2 \mathrm{H}_{2} \mathrm{O}$ was synthesized via Mecheri’s procedure (Mecheri, 2006).

\subsection{The morphology of polymer composites}

The SEM device was used to examine the dispersionstatus of particles in polymer composites. PS and PS-50\% composite, shown in Figure 1.

\subsection{The crystallinity of $\mathrm{WO}_{3} .2 \mathrm{H}^{2} \mathrm{O}$}

The XRD spectrum of $\mathrm{WO}_{3} .2 \mathrm{H}^{2} \mathrm{O}$ is shown in Figure 2. As seen in figure 2, $\mathrm{WO}_{3} .2 \mathrm{H}_{2} \mathrm{O}$ showed good crystallinity and had clear diffraction peaks. The pattern is in good harmony with the prior literature; statements on the structural documentation of hydrated tungsten oxide (Mecheri, 2006).

\subsection{Preparation of PS-composites}

After PS and $\mathrm{WO}_{3} .2 \mathrm{H}_{2} \mathrm{O}$ were dissolved in dimethylformamide (DMF) at $70^{\circ} \mathrm{C}$ for $2 \mathrm{~h}$, PStungsten(VI) composites prepared $\mathrm{PS} / \mathrm{WO}_{3}$ composite solutions were acquired by changing the weight $\%$ of $\mathrm{WO}_{3} .2 \mathrm{H}_{2} \mathrm{O}$. The combination was cast on a silicon plate and cured between $80-85^{\circ} \mathrm{C}$ for 1 day (Korpinar, 2020). Then they were dried at $100^{\circ} \mathrm{C}$ (Scheme 1 ). 
Scheme 1:Synthesis of Polystyrene and Polystyrene-Tungsten(VI) Oxide composites

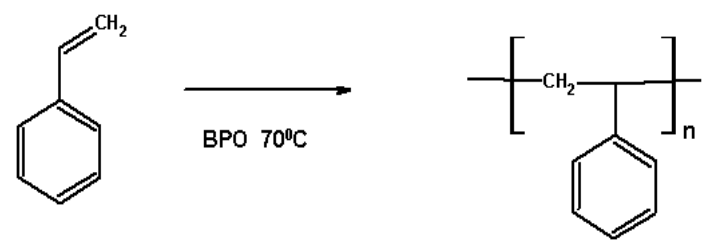

Polystyren+Tungsten(VI)oxide

(10\%-20\%-30\%-40\%-50\% ratios) $\quad 80-85^{\circ} \mathrm{C}$ DMF

Polystyrene-Tungsten(VI) Oxide composites

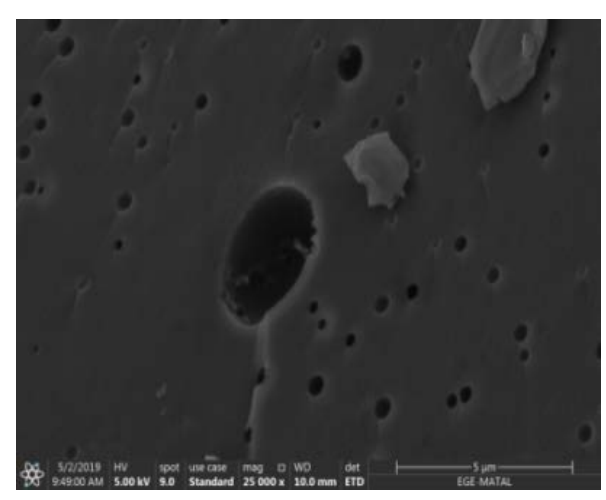

(a)

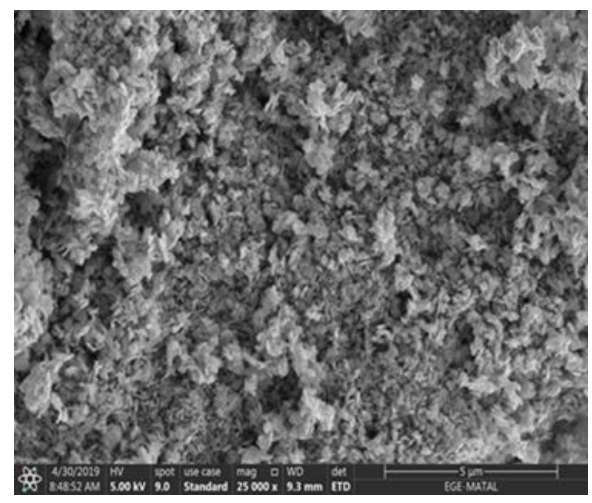

(b)

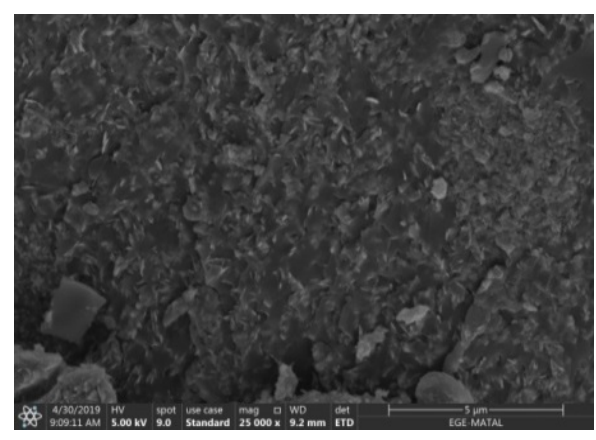

(c)

Figure 1: SEM image of Polystyrene (a), WO3 $2 \mathrm{H}_{2} \mathrm{O}$ (b), Polystyrene-50 wt $\%$ Tungsten(VI) Oxides (c). 


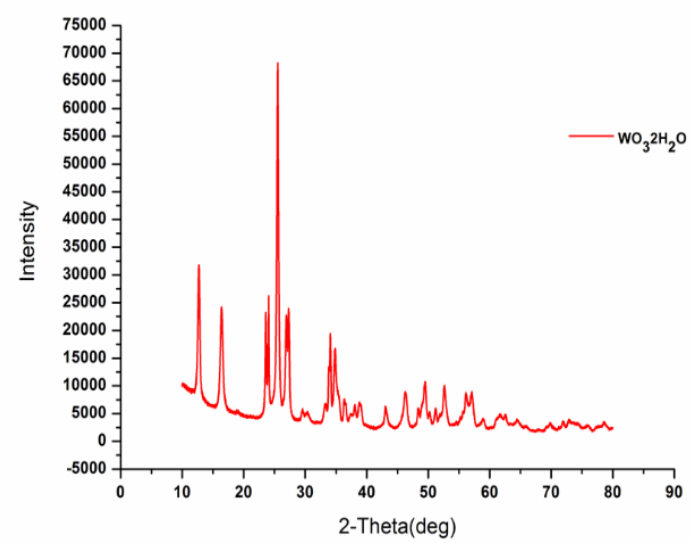

Figure 2: XRD patterns of $\mathrm{WO}_{3} .2 \mathrm{H}_{2} \mathrm{O}$ powder.

\subsection{Measurements of gamma-ray attenuation coefficients}

The schematic diagram of the experimental mechanism is shown in Figure $3 .{ }^{137} \mathrm{Cs}(662 \mathrm{keV})$ and ${ }^{60} \mathrm{Co}$ (1172 and $1332 \mathrm{keV}$ ) IAEA gamma point sources were placed in a lead collector 20 $\mathrm{cm}$ away from the detector. Another lead collimator was installed right in front of the detector. Gamma-ray densities were measured with a 3x3 NaI(Tl) detector (CANBERRA), which has an energy resolution of $7.5 \%$ for gamma energy of $661.66 \mathrm{keV}$ for ${ }^{137} \mathrm{Cs}$. In addition to the collimator installation used to guard the detector against any dispersed radiation and to provide gamma rays passing through the sample in a narrow parallel beam; detectors, collectors, and polymer composites are also preserved in $110 \mathrm{~mm}$ thick lead bricks coated with $1.5 \mathrm{~mm}$ copper foil from the inside. The detector was combined into a photomultiplier tube, front amplifier, spectroscopy amplifier, and PC-based multichannel pulse height analyzer. The resulting gamma measurements were recorded in Genie2000 software.

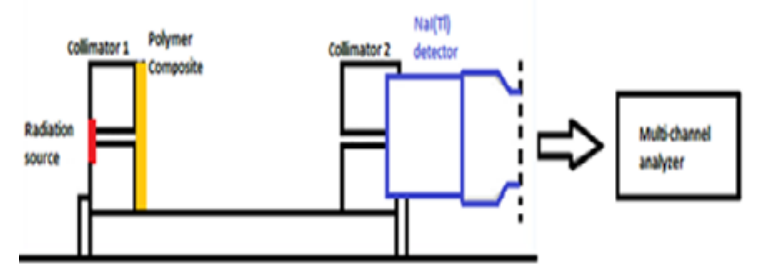

Figure 3: Schematic drawing of the experimental setup.

The gamma-ray transmission method was used to determine gamma-ray slimming coefficients. In this method, pulse-elevation spectrums of gamma densities for background count, initial density $\left(\mathrm{I}_{0}\right)$ without any composite samples, and densities transmitted for unlike thinness ( 1,2 , and $3 \mathrm{~mm}$ ) for $\mathrm{PS}-\mathrm{WO}_{3} \cdot 2 \mathrm{H}_{2} \mathrm{O}$ (I) at five diverse concentration levels (between $10 \%$ and $50 \%$ by weight) composite samples were taken for 900 seconds. By reducing background counts, net counts were achieved at the full energy summit. 


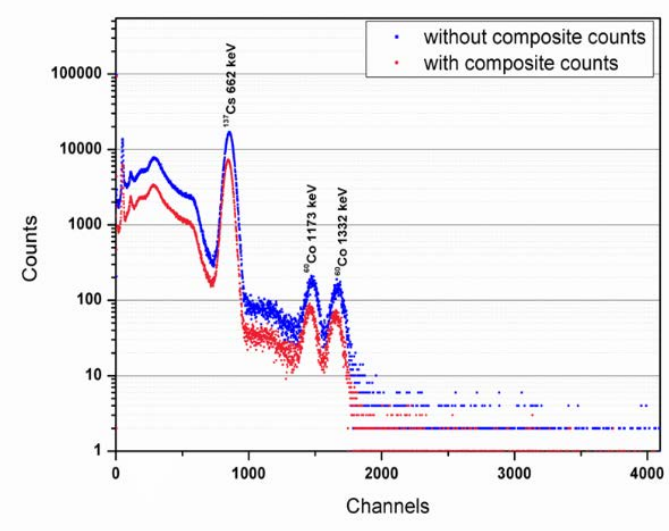

Figure 4: The pulse-height spectrum of gamma intensities for the PS-50\% $\mathrm{WO}_{3}$.

The obtained net counts were applied to Lambert's Law to evaluate the linear gamma attenuation coefficients of the polymer composites (Eq.1).

$$
I=I_{0} e^{-\mu x}
$$

Where $\mathrm{I}_{0}$ is the incident intensity at zero absorber thickness; (I) is the gamma radiation intensity transmitted through composite sets of different thicknesses; $\mathrm{x}$, composite thickness in $\mathrm{cm}$ and $\mu$, linear attenuation coefficient in $\mathrm{cm}^{-1}$. Using Eq.1

$$
\mu=\frac{\ln I_{0} / I}{X}
$$

The slope of the curve obtained for the variation of the natural logarithm of the net $\left(\mathrm{I}_{0} / \mathrm{I}\right)$ counts achieved for 3 different absorber thicknesses ( 1, 2, and $3 \mathrm{~mm}$ ) of a PS- $\mathrm{WO}_{3} \cdot 2 \mathrm{H}_{2} \mathrm{O}$ composite with the absorber thicknesses gave the linear attenuation coefficient. This method was repeated for each PS composite containing 10, 20, 30, 40 and 50 wt. \% $\mathrm{WO}_{3} .2 \mathrm{H}_{2} \mathrm{O}$.

\subsection{Theoretical method for calculating gamma-ray attenuation coefficients}

To calculate theoretical linear slimming coefficients, the theoretical mass slimming coefficients were obtained primarily using XCOM software developed by Berger and his colleagues. This program uses relative basic fractions of materials to calculate mass slimming coefficients. Thus, the relative elemental fractions of $\mathrm{PS}-\mathrm{WO}_{3} \cdot 2 \mathrm{H}_{2} \mathrm{O}$ composites are listed in Table l. The density of polymer composite materials was calculated according to the literature and given in Table 1 (Osei-Mensah, 2012; finally, theoretical linear slimming coefficients were considered by multiplying mass slimming coefficients by the density of the composite (Equation. 2).

$$
\mu_{\mathrm{m}}=\mu / \rho
$$

Where $\rho$ presents the density of the composites in $\mathrm{g} / \mathrm{cm}^{3} ; \mu_{\mathrm{m}}$ and $\mu$ the mass attenuation coefficient in $\mathrm{cm}^{2} / \mathrm{g}$ and the linear attenuation coefficient in $\mathrm{cm}^{-1}$, respectively. 
Table 1: The densities and the chemical compositions of the PS- $\mathrm{WO}_{3}$. $2 \mathrm{H} 2 \mathrm{O}$ composites.

\begin{tabular}{cccccc}
\hline $\begin{array}{c}\text { Polymer- } \\
\text { composites }\end{array}$ & $\mathrm{C}$ & $\mathrm{H}$ & $\mathrm{O}$ & $\mathrm{W}$ & $\begin{array}{c}\text { Density } \rho \\
\left(\mathrm{g} / \mathrm{cm}^{3}\right)\end{array}$ \\
\hline $\begin{array}{c}\text { PS } \\
\text { PS 10\% } \mathrm{WO}_{3}\end{array}$ & 73.31 & 7.69 & - & - & 1.04 \\
$\mathrm{PS} \mathrm{20 \%} \mathrm{WO}_{3}$ & 57.27 & 4.98 & 4.12 & 18.74 & 1.14 \\
$\mathrm{PS} \mathrm{30 \%} \mathrm{WO}_{3}$ & 47.21 & 3.92 & 10.12 & 38.75 & 1.40 \\
$\mathrm{PS} 40 \% \mathrm{WO}_{3}$ & 37.13 & 3.09 & 12.38 & 47.4 & 1.58 \\
$\mathrm{PS} \mathrm{50 \%} \mathrm{WO}_{3}$ & 28.59 & 2.38 & 14.29 & 54.74 & 1.82 \\
\hline
\end{tabular}

\subsection{Transmission parameters}

Transmission parameters define the effectiveness of gamma-ray screening of materials. Thus, parameters were calculated as a half-value layer (HVL), tenth value layer (TVL) and average freeway (MFP). A half-value layer (HVL) is the absorbent thickness required to halve the photon density in the event. Likewise, the tenth value layer (TVL) is the absorbent thickness required to reduce the photon density in the event to ten. Also, the average freeway (MFP) is defined as the average distance between the two subsequent interactions of photons (Gökçe, 2018; Akkurt, 2010). Therefore, HVL, TVL, and MFP were calculated from experimental linear slimming coefficients following (Eq. 3), (Eq 4), and (Eq. 5) respectively.

$$
\begin{gathered}
H V L=\frac{\ln 2}{\mu} \\
T V L=\frac{\ln 10}{\mu} \\
M F P=\frac{1}{\mu}
\end{gathered}
$$

\section{Results and Discussion}

In the current study, the polystyrene was effectively synthesized via radical polymerization method. Subsequently, PS-tungsten(VI) oxide composites were prepared in DMF. For different radiation shielding materials, various polymers and inorganic salts are incorporated. Several composites were prepared with tungsten to reduce the intensity of radiation by several researchers. Tungsten and styrene-butadiene copolymer were set and reported theoretically it's effectiveness in stopping electrons in radiotherapy (Gorbatkina, 2007; Yue, 2009; Bobadilla-Sánchez, 2009; Martínez-Barrera, 2013; Durkee, 2005). In many other studies, a metallic form of tungsten powder was obtained by combining physically with the polymer and mixtures in the current study, the polystyrene composites were synthesized since there are no such composites in the literature, it is the most used plastic for general and polystyrene is resistant to radiation. So we obtained in a homogeneously dispersed and harder stacked structure polystyrene composites. The homogeneities of polymer composites were tested by SEM analysis. Fig. 1 shows the surface SEM images of $\mathrm{PS}, \mathrm{WO}_{3} .2 \mathrm{H}_{2} \mathrm{O}$, and $\mathrm{PS}-50 \mathrm{wt} \%$ 
tungsten(VI) oxides composites. By incorporation of $\mathrm{WO}_{3} .2 \mathrm{H}_{2} \mathrm{O}$ into the polymer matrices, it has been seen that the $\mathrm{WO}_{3}$ particles are well dispersed in the polymer matrices (Salama,2019; Sayyed, 2018; Verdipoor,2018).

\subsection{Gamma Shielding Properties of Polystyrene}

The current study was conducted to investigate gamma shielding properties of polystyrene, As a result, the linear gamma attenuation coefficients and transmissions parameters of the PS composites were determined and given in Table 2.

The variation of the experimental linear gamma attenuation coefficients according to tungsten (VI) oxide (\%10-\%50) additives for $662 \mathrm{keV}, 1173 \mathrm{keV}$, and $1332 \mathrm{keV}$ energies were illustrated in Fig 5. The Tungsten(VI) oxide additives increased the linear attenuation coefficient of PS 50\% $\mathrm{WO}_{3}$ by $~ 80 \%$ for $662 \mathrm{keV}, ~ 58 \%$ for $1173 \mathrm{keV}$ and $~ 52 \%$ for 1332 $\mathrm{keV}$ compared to the PS. There was a noticeable increase in the linear attenuation coefficients of the composites with an increase in the percentage of tungsten (VI) oxide. Similar results on tungsten (VI) oxide additives in poly (hydroxyethyl methacrylate) composites were reported in another study of the authors (Korpinar,2020).

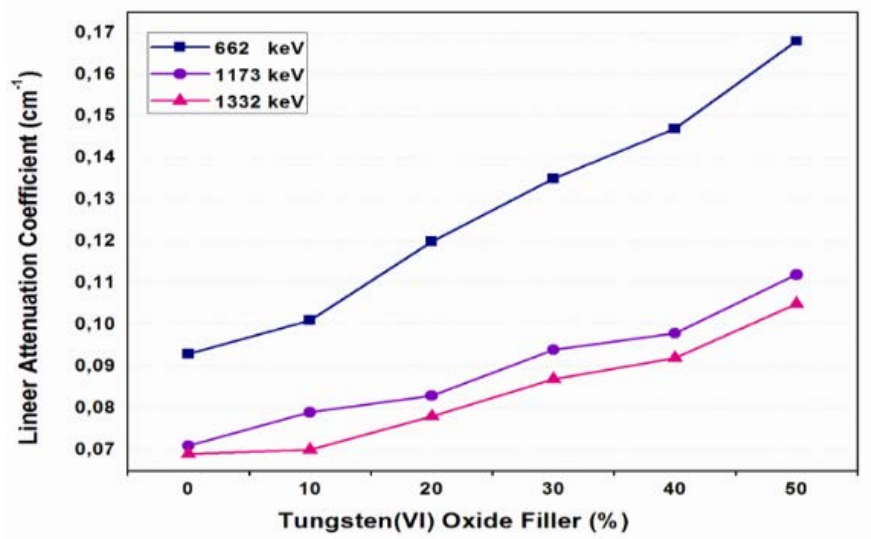

Figure 5: The variation of linear attenuation coefficients with Tungsten (VI) additive.

Since different gamma energies may be encountered in different applications, the linear attenuation coefficients of the polymer-composites were also theoretically obtained over a wide energy range of $1 \mathrm{keV}$ and $108 \mathrm{keV}$. As known, three major interaction mechanisms which are photoelectric absorption, Compton scattering, and pair production play an important role in interacting gamma-rays with the matter. The photoelectric absorption is the predominant mode of interaction for gamma rays of relatively low energy. This absorption processing is also enhanced with the high atomic number $\mathrm{Z}$ of the absorber material, proportionally Z4-52,3. Thus, it was seen that the photoelectric effect became the dominant mechanism of interaction with the addition of a high atomic number $\mathrm{Z}$ of tungsten. 


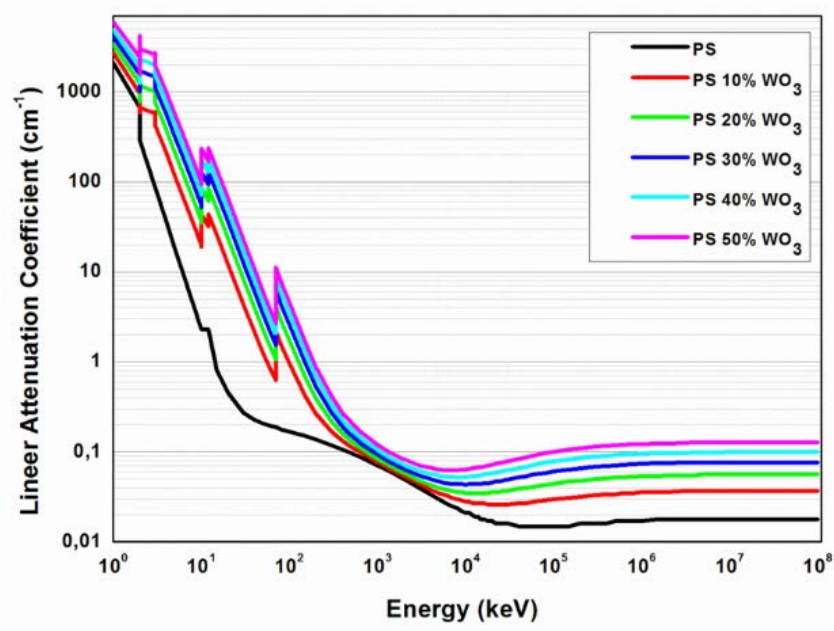

Figure 6: The variation of the theoretical linear attenuation coefficients of the PSTungsten(VI) Oxide composites with photon energies.

To make clearer the gamma shielding properties of polystyrene, the transmissions parameters of the PS composites were calculated besides the linear attenuation coefficients (Table 2). The variation of the parameters such as half-value layer $(\mathrm{HVL}, \mathrm{cm})$, tenth-value layer (TVL, $\mathrm{cm})$ and mean free path (MFP, cm) with tungsten(VI) oxide additive for 662, 1173 and $1332 \mathrm{keV}$ photon energies were illustrated in Fig. 7. The lower absorber thickness for PS-50\% $\mathrm{WO}_{3} .2 \mathrm{H}_{2} \mathrm{O}$ about $35-20 \%$ compared to PS was quite enough to stop the gamma-rays.

Table 2: Gamma shielding properties of the PS- $\mathrm{WO}_{3} .2 \mathrm{H}_{2} \mathrm{O}$ composites.

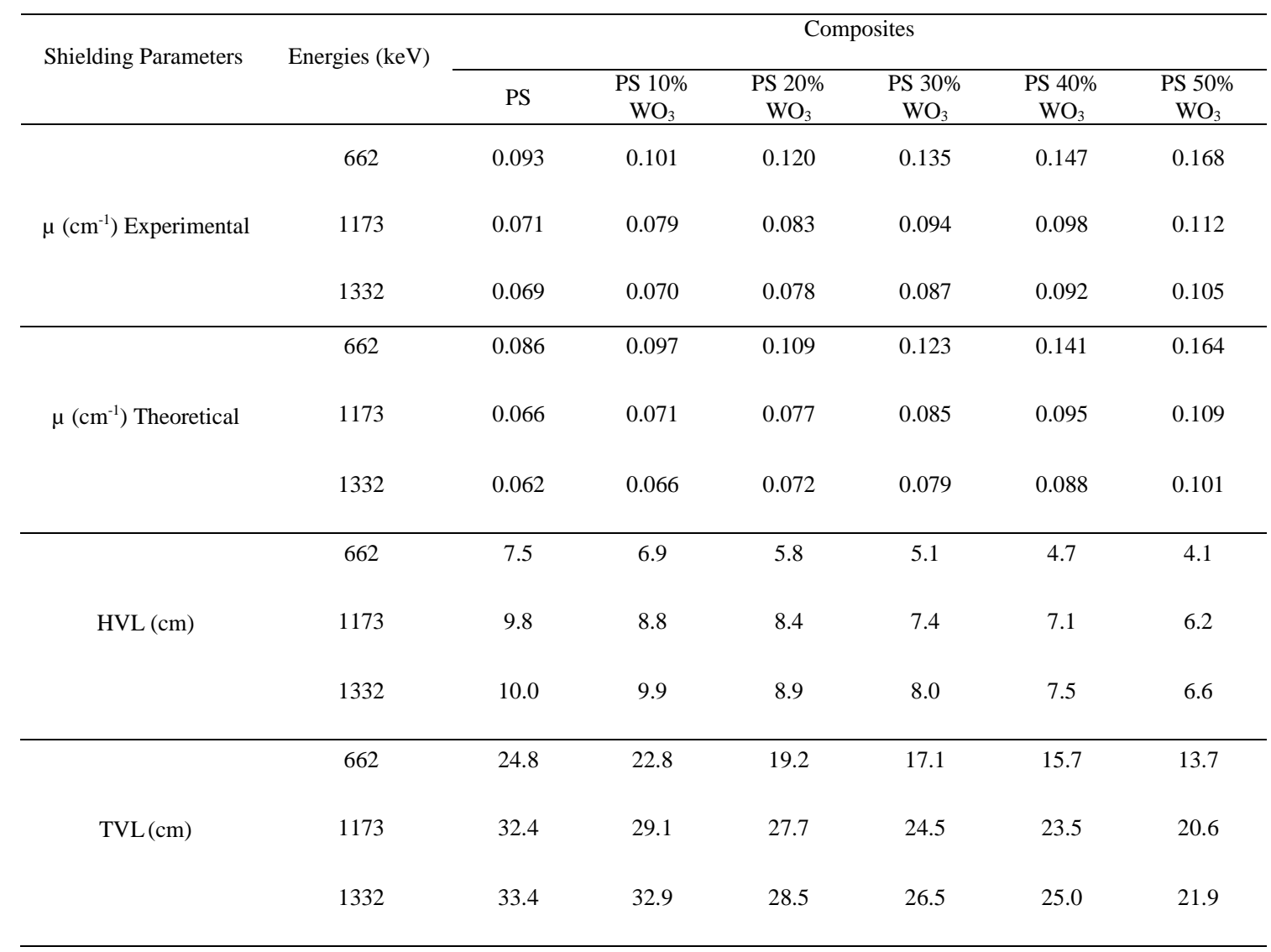




\begin{tabular}{lccccccc}
\hline & 662 & 10.8 & 9.9 & 8.3 & 7.4 & 6.8 & 6.0 \\
MFP (cm) & 1173 & 14.1 & 12.7 & 12.0 & 10.6 & 10.2 & 8.9 \\
& 1332 & 14.5 & 14.3 & 12.8 & 11.5 & 10.9 & 9.5 \\
\hline
\end{tabular}

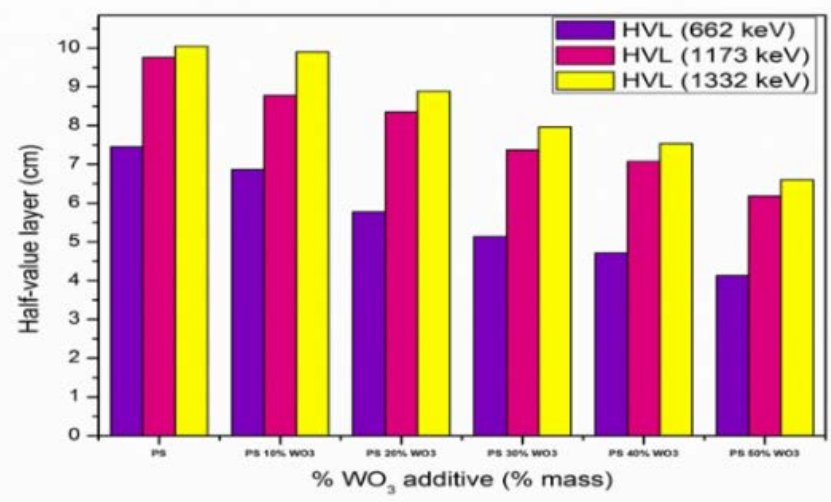

(a)

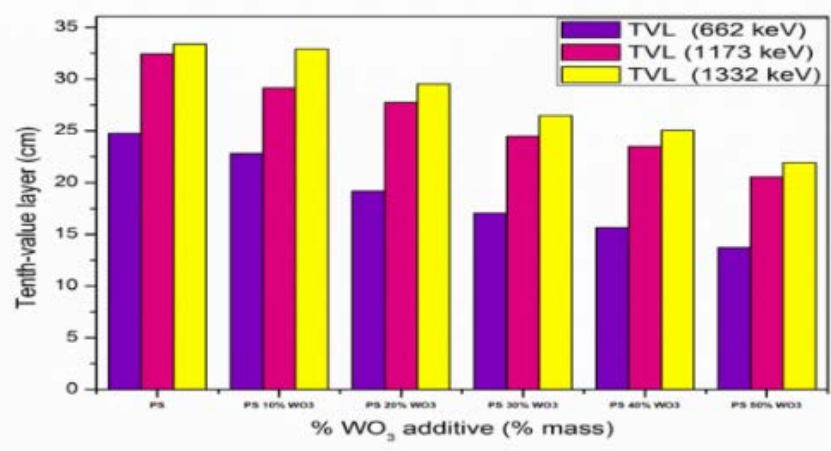

(b)

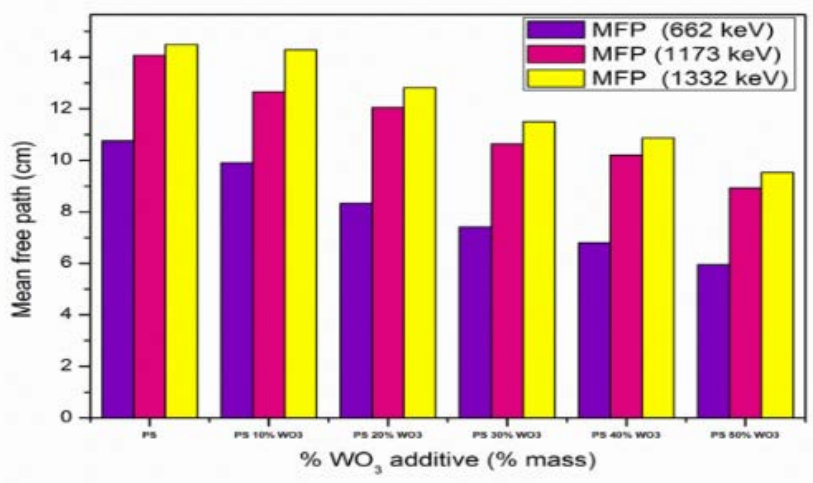

(c)

Figure 7: The variation of the parameters HVL (a), TVL (b), MFP (c), of PS and PS tungsten(VI) composites with tungsten(VI) oxide. 


\subsection{Thermal degradation of Polystyrene}

Thermogravimetric curves of PS and PS-tungsten(VI) oxide composites containing between $10 \mathrm{wt} \%$ and $50 \mathrm{wt} \%$ are shown in Figure 8 (before radiation) and Figure 9 (after radiation). In most cases, the thermal degradation of samples is a one-step process. The thermal stability of composites is enhanced by radiation. This may be due to breakage and cross-linking of materials known to be one of the main sources for changing the internal structure of ionization radiation on polymers and thus lead to a wide area range of interrelated changes in physicochemical properties. This type of treatment may cause the molecular chains of polymers to be cross-linked and cut, or even to deteriorate and break down macromolecules, i.e. the formation of molecules with smaller chain lengths, or to may cause a change in the number or structure of the bonds (Lim, 1990; Shintani, 1991; You;2013). Another noticeable feature is that high char yields of non-irradiated PS composites in comparison with irradiated PS ones. The char yields of the radiationated polymers and polymer composites are enhanced when compared with iraditionated ones.

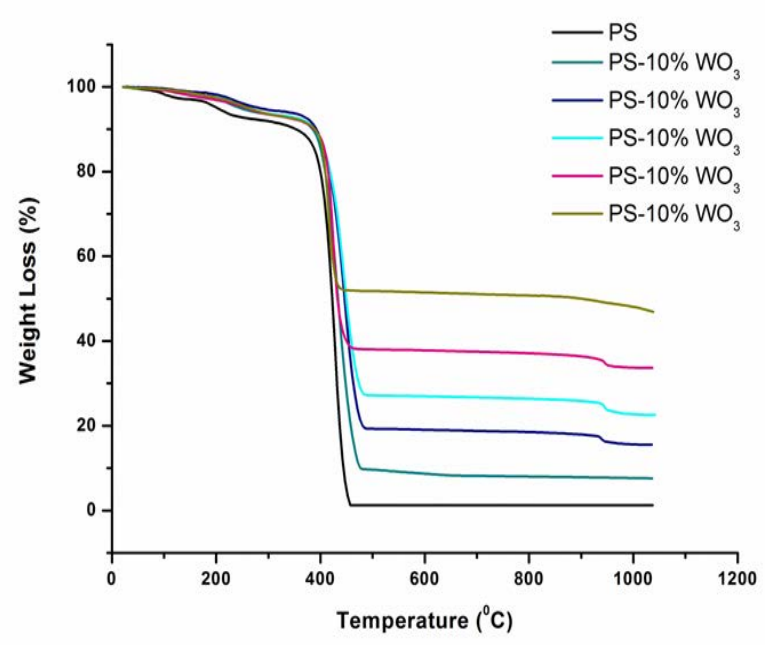

Figure 8: Thermal degradation curves of PS and PS-composites before irradiation.

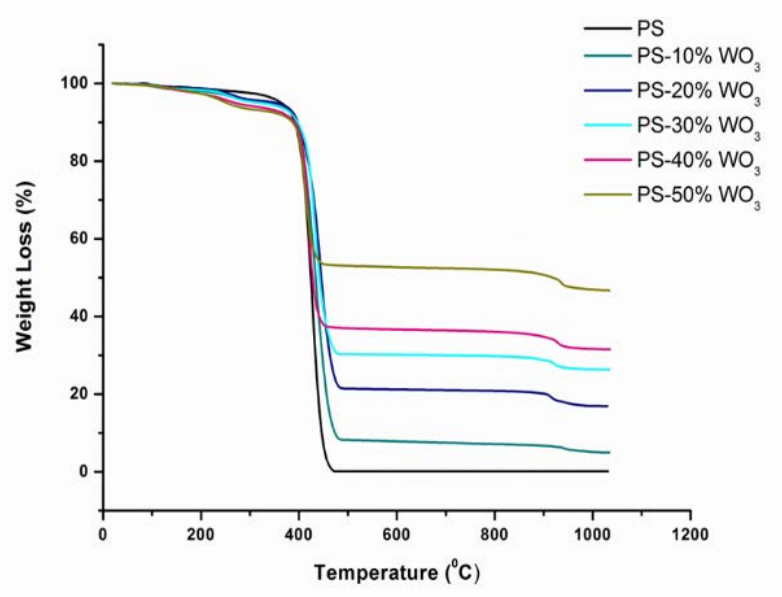

Figure 9: Thermal degradation curves of PS and PS-composites after irradiation. 


\section{Conclusion}

In the current research, polystyrene was synthesized successfully based on radical polymerization method, to prepare the PS-tungsten (VI) oxide composites mixtures were set by dissolving in dimethylformamide. After that, the polystyrene-composites were poured into the silicone cup and cured between $80-85^{\circ} \mathrm{C}$. The polymerization reaction was confirmed by spectroscopic analysis. The linear gamma attenuation coefficients of PS and PS composites amplified with the amount of tungsten (VI) oxide and this result verified gamma-rays and spectroscopic analysis. Also, the calculations on other shielding parameters showed the needed absorber thickness decreased expressively for the PS- $50 \% \mathrm{WO}_{3} \cdot 2 \mathrm{H}_{2} \mathrm{O}$. The studies on thermal degradation of examined polymer composites indicated that the thermal stability of the samples was improved with irradiation and resulted in high char yield.

\section{References}

Dawood , A. F. M. S. K. 2017. "Study of Some Shielding Parameters of Gamma Rays and Fast Neutrons for Various Shielding Materials", Int. J. Sci. Res., 6, 239-245.

Knoll, G. F. (2000). "Radiation Detection and Measurement Third Edition", New York, USA.

Tsoulfanidis, N. 1995. "Measurement and Detection of Radiation" New York, U.S.A.

Harrison, C. Weaver, S. Bertelsen, C. Burgett, E. Hertel, N. Grulke, E. 2008. "Polyethylene/boron nitride composites for space radiation shielding", J. Appl. Polym. Sci. 109, 2529-2538.

Erdem, M. Baykara, O. Doĝru, M. Kuluöztürk, F. 2010. "A novel shielding material prepared from solid waste containing lead for gamma ray", Radiat. Phys. Chem.79, 917-922.

Lamarsh, J. R. Baratta, A. J. 2001. "Introduction to nuclear engineering", New York, USA.

Gorbatkina, Y. A. Ivanova-Mumzhieva, V. G. Ulyanova, T. M. 2007. "Adhesiveness of an epoxy oligomer filled with aluminum oxide powders", Polym. Sci. Ser. C.,49, 131-134.

Yue, K. Luo, W. Dong, X. Wang, C. Wu, G. Jiang, M.Zha, Y. 2009. "A new lead-free radiation shielding material for radiotherapy" Radiat. Prot. Dosimetry, 133,256-260.

Bobadilla-Sánchez, E. A. Martínez-Barrera, G. Brostow, W. Datashvili, T. 2009. "Effects of polyester fibers and gamma irradiation on mechanical properties of polymer concrete containing CaCO3 and silica sand", Express Polym. Lett., 3. 615-621.

Martínez-Barrera, G. Vigueras Santiago, E. Hernández López, S. Gencel, O. Ureña-Nuñez, F. 2013. "Polypropylene Fibers as Reinforcements of Polyester-Based Composites", Int. J. Polym. Sci, 2013, 1-6.

Durkee, R. R. 2005. "High Density Composites Replace Lead" Newyork, U.S.A.

Mecheri, B. DEpifanio, A. Di Von, M.L. Traversa, E. Licoccia,S. Miyayama, M. 2006, "Sulfonated Polyether Ether Ketone-Based Composite Membranes Doped with a Tungsten- 
Based Inorganic Proton Conductor for Fuel Cell Applications", J. Electrochem. Soc., 153, 463-467.Körpınar, B. Canbaz Öztürk, B. Çam, N. F. Akat, H. 2020. "Radiation shielding properties of Poly(hydroxylethylmethacrylate)/Tungsten (VI) oxide composites", Mater. Chem. Phys. 239, 1-8.

Osei-Mensah, W. Fletcher, J. J. Danso, K. A. 2012. "Assessment of Radiation Shielding Properties of Polyester Steel Composite using MCNP5", International Journal of Science and Technology, 2, 1-6.

Muisener, P. A. O. Clayton, L. DAngelo, J. Harmona, J.P. 2002, "Effects of gamma radiation on poly(methyl methacrylate)/single-wall nanotube composites", J. Mater. Res.. 17, 25072513.

Gökçe, H. S. Öztürk, B. C Çam, N. F. Andiç-Çakır, Ö. 2018, "Gamma-ray attenuation coefficients and transmission thickness of high consistency heavyweight concrete containing mineral admixture", Cem. Concr. Compos. 92, 56-69.

Akkurt, I. Akyildirim, H. Mavi, B. Kilincarslan, S. Basyigit, C. 2010."Photon attenuation coefficients of concrete includes barite in different rate" Ann. Nucl. Energy 37(7), 910-914.

Salama, E. Maher, A. Youssef, G. M. 2019."Gamma radiation and neutron shielding properties of transparent alkali borosilicate glass containing lead", J. Phys. Chem. Solids, 131, 139-147.

Sayyed M. I., Elbashir B. O., Tekin H. O., Altunsoy E. E., Gaikwad D. K. 2018. "Radiation shielding properties of pentaternary borate glasses using MCNPX code", J. Phys. Chem. Solids, 121,17-21.

Verdipoor, K. Alemi, A. Mesbahi, 2018, "A. Photon mass attenuation coefficients of a silicon resin loaded with WO3, PbO, and Bi2O3 Micro and Nano-particles for radiation shielding", Radiat. Phys. Chem., 147, 85-90.

Lim, S. L. Fane, A. G. Fell, C. J. D. 1990. "Radiation-induced grafting of regenerated cellulose hollow-fiber membranes", J. Appl. Polym. Sci. 41, 1609-1616.

Shintani, H. Kikuchi, H. Nakamura, A. 1991. "Effects of gamma-ray irradiation on the change of characteristics of polyurethane", Polym. Degrad. Stab., 32, 17-30.

You, F. Li, Y. Zuo, Y. Li, J. 2013, "The Influence of Gamma-Ray Irradiation on the Mechanical and Thermal Behaviors of nHA/PA66 Composite Scaffolds", Sci. World J., 2013,1-6. 